Aftied Newion On the Zoology d ancient Europe. Sus, 319, Macmillan, Landan 1862. 



\title{
ON THE ZOOLOGY OF
}

\section{A NCIENT EUROPE:}

A PAPER READ BEFORE THE

CAMBRIDGE PHILOSOPHICAL SOCIETY,

ON MONDAY, 31st MARCH, 1862.

BY

\author{
ALFRED NEWTON, M.A., \\ FELLOW OF MAGDALENE COLLEGE, CAMBRIDGE, \\ F.L.S., F.Z.S., F.C.P.S., ETC.
}

MACMILLAN AND CO., LONDON AND CAMBRIDGE: M.DCCC.LXII. 
Digitized by the Internet Archive in 2019 with funding from University of Toronto 


\section{ON THE Z00LOGY OF ANCIENT EUROPE.}

The subject to which I invite your attention this evening, possesses, I trust, an interest of its own sufficient to warrant me in bringing it to your notice. Were it otherwise and depending alone upon my powers to render it worthy of consideration, I should hesitate long before I ventured to obtrude it upon the Philosophical Society of the University of Cambridge. As it is, I have no small fear lest the theme should suffer in my hands, and I must therefore crave your utmost indulgence while making some remarks on the Zoology of Ancient Europe.

Many of those whom I have the honour to address, may probably, at some time or other, have been led to speculate on what must have been the condition and appearance of this quarter of the globe at the period when the rude ancestors of its present civilized inhabitants first explored its bleak mountains, its trackless forests, its wilds "immeasurably spread," and its waters hitherto undisturbed by the plashing oar or the cleaving prow-all of which, either through our own actual observation or the accounts of others, are now so familiar to us. I shall not try to depict to your imagination the probable aspect even of the natural features of primitive Europe-though these, in all likelihood, have not undergone much alteration,-still less shall I attempt a complete description of the wild animals, its ancient denizens; for I believe that as yet the materials do not exist from which to form anything like a perfect picture of that remote age. I can only pretend to touch upon a few salient points, on which light has been already thrown.

But before I proceed further, I must state the limits within which I intend to confine my present remarks. In the first place, 
I wish to treat the subject-the Zoology of Ancient Europeentirely without reference to Anthropological or Ethnological considerations. It is notorious that the greatest possible differences of opinion prevail in this respect, even among those who have most applied themselves to these questions; and it would ill-become me, who make no pretensions to those special branches of study, to offer any observations thereon, which could only be as crude as they would be impertinent. But, on the other hand, I do not preclude myself from making reference to human agency, where it is almost universally admitted to have existed, not only with regard to the checks or the encouragement it may have given to certain species, but also because it is, as I shall presently show, through human agency, though unconsciously exercised, that a great, and perhaps the most instructive, portion of the evidence at my disposal is to be gathered.

Next I have to say, that though the period of which I am about to treat is in all conscience sufficiently remote, I have not the inclination, any more than I have the ability, to trespass on the domain of Palæontology. The epoch to which I am about to refer is that which immediately succeeded the latest æra, properly called "geological," whenever that closed; and indeed forms the sort of debateable border-land between the realm of the former science and that of Zoology. To this, I may perhaps be allowed, in the absence of a better name, to apply that of ARCHenTOLOGY, as at once expressing its immediate relations both to Archæology and to Palæontology.

There is another reason, as it seems to me, why I should content myself with these limits. Whatever grounds may exist, and I utter no opinion as to their validity, for the belief that Man was contemporary with animals such as the Mammoth for example; it has not been shown that the area of the earth's surface, at present occupied by what we call Europe, then bore any great geographical resemblance to the modern continent. Sir Charles Lyell has presented us with a map, shewing the districts which are now dry land, but which have certainly been submerged since the Tertiary epoch, and though he especially warns us against the supposition that all these tracts were simultaneously covered by the ocean, it is impos- 
sible (as, with all deference to geological authorities, appears to me,) in the actual state of our knowledge, to say how great or how small an extent of submergence took place at any given period. And referring now, for the last time, to the much-discussed question of the contemporaneous existence of the human race with peculiarly palæontological species, though it has been for some time surmised that the gigantic Irish Deer (Megaceros hibernicus), and, more lately, that the Wall-nosed Rhinoceros (Rhinoceros tichorhinus), and the great Cave Bear (Ursus spelceus), were coeval with Man, and were hunted and slain by him, yet the evidence in these cases is still under-investigation, and it will be safer not to include them among those animals which I shall here consider. The Irish Deer, indeed, perhaps, has the strongest claims on our attention in this particular; and some naturalists there are, especially among the patriots of the sister kingdom, who have announced their unequivocal belief in its persistence even into the historic period, while others do not hesitate to recognize in it the mysterious "Shelch" of the Nibelungen Lied. One of the former- the late Mr. Glennon, of Dublinwas firm in this creed; and, about eighteen months ago, I had the pleasure of holding some very interesting conversation with him on the subject; but he failed to convince me of the soundness of his arguments, and I hope I am doing his memory no wrong, when I say that the enthusiasm he displayed, tinged, perhaps, with no small trace of romance, was the principal cause of my unwilling scepticism.*

It would be obviously impossible for me to include within the scope of a paper like this, a notice of all the species which have been asserted, on even the surest authority, to have been man's contemporaries in Europe from the earliest period. According to a tabular statement given by Professor Owen, in his History of British Fossil Mammalia, sixteen years ago, it would appear that no less than thirty-five species of British mammals alone might be included in this category, and the number would be much swelled if to them were added the species of which traces have since been found in the same deposits with human relics. It is sufficient to say, that of

* An interesting discussion on this subject is reported as having taken place at the meeting of the Geological Society of Dublin, 11th December, 1861. 
these 35, 17 have been discovered in the drift and fresh-water strata usually considered as belonging to the same age, 22 in caves, and 23 in fen or turbary deposits. Of the other classes of vertebrates, the remains fully recognized are by no means so numerous; of invertebrates I believe the number is enormous, if not incalculable. Now, merely to read a bare list of these vertebrates would occupy a long time, and would hardly be profitable. I must, therefore, ask you to allow me to select for myself those species which, from one cause or another, seem to me most deserving of attention, and I shall take the liberty of doing this without regard to any systematic arrangement. We are told on authority, which few in this University will desire to controvert, that "Natural History, when systematically treated, rigorously excludes all that is historical; for it classes objects by their permanent and universal properties; and has nothing to do with the narration of particular or casual facts." Now, it is with particular and casual facts, as they are termed by the learned author of the "History of the Inductive Sciences" (vol. iii, p. 532, ed. 1847), that I have to do to-night, and, accordingly, I here take leave of the general observations in which I have ventured to indulge.

Before all other instances I will mention one, of which certainly many in this room have a far greater knowledge than myself. On the evidence of classical authors, unsupported, as far as I know, by the discovery of any fossil remains, I claim without hesitation for the "King of Beasts" a place in the fauna of Ancient Europe. We are disposed at first sight to consider the presence of the larger carnivora as confined to the tropical or quasi-tropical regions of the globe. Allow me to say that this is a very great error. I pass over extinct species, such as the Machoerodus or the Felis spelcea, whose relics the unwearied researches of the late Dr. Buckland unequivocally detected in Kent's Hole and the Kirkdale Caverns-for we know not the climatic conditions under which those formidable creatures once existed in this country. But at the present day it is incontestible that the Tiger (Felis tigris) - specifically identical with the treacherous inhabitant of the jungles of Bengal-not only crosses the snows of the Himalayah Mountains, as, in truth, has long been known (Pallas, Zoogr. Ross.-Asiat. I. p. 16), but even 
extends its range throughout China, to that district-the valley of the river Amoor-by which the boundaries of the Russian Empire have recently been "rectified." The labours of Von Middendorff (Sibir. Reise, I. i. p. 75), Von Schrenck (Reisen, \&c., im Amur-lande, I. pp. 90 et seqq.), and others, have shown that it is an ordinary resident at all seasons of the year, and frequently destructive to men and cattle, about the mouth of the river Ussuri, in north latitude $48^{\circ}$ (nearly that of Vienna), and also that it even passes over the ice in latitude $52^{\circ}$ (almost as far north as our present place of meeting), to devastate the island of Saghalien, where, according to Keith Johnstone's "Physical Atlas," the mean temperature is that of Iceland, while the winters are as severe as those of St. Petersburg. I therefore do not question that the legends of Ancient Greece may have had a strictly local origin, when they assert that the first settlers in Argolis met with Lions there. The early trophy of Hercules-the hide of the Nemæan monsterseems to me far less mythical than most of that hero's attributes. Again, too, I need scarcely remind my audience of the numerous allusions to this animal, which are to be found in Homer, nor of the statement of Herodotus (Polyhymnia, capp. 125, 126) respecting the existence of Lions in Thrace, and the ravages they committed there on the Camels of Xerxes. I hope I shall not be supposed to affect a classical knowledge I can only admire in others, but, speaking merely as a zoologist, I see no objection to the story.

When first I thought of offering to this Society some remarks on the subject I have chosen, I had been fully in hopes that I should have had the pleasure of announcing to you a number of important facts, known but to few in England, and of which no account had appeared in our language. But this privilege has been denied me. My talented friend Mr. Lubbock, very recently it is true, has given a concise, yet complete, narrative of the extraordinary results of the researches which for some years past have been carried on in two European countries-Denmark and Switzerland-by investigators, as their labours show, fully competent to the task. Still it is possible that among my hearers there may be some who have not seen that gentleman's masterly papers, published in the last two numbers of the "Natural History Review" (October, 1861, and 
January, 1862). It is incumbent on me to declare that I am greatly indebted to the accurate summary of facts, contained in those articles, relating to the remarkable "Kitchen-Middens" of Denmark, and the scarcely less wonderful "Pile-Buildings" of Switzerland;though respecting the former, I was at least prepared to furnish a short account, derived from original sources, while of the latter I was already acquainted with the principal features.

To give a rapid sketch of these interesting discoveries. It is now several years since the attention of enquiring minds in Denmark was particularly attracted to some curiously composed formations, chiefly made up of sea-shells, intermingled with bones of the higher animals, and a few flint implements, which are found at many points near or along the shores of that kingdom. These beds are of very considerable dimensions. They generally present a depth of from three to five feet, but at a few stations the mass attains a thickness of ten feet. They sometimes reach to a length of a thousand feet, with an irregular width varying from one hundred and fifty to two hundred feet. Various theories had been broached to account for their origin. That which seems to have been most generally received, was that they were ancient raised sea-beaches-for, as is well known, the proofs of an upheaval of the land throughout the Scandinavian and Cimbric Peninsulas, and their adjoining Archipelagoes, are indubitable. One feels almost tempted to please one's fancy by realizing in this wonderful movement the story told of the old Danish king, and to imagine that though the tides refused to obey his behest-as they did the order of a still mightier potentate, the Persian invader of ancient Greece,-yet that the land, more tractable, by rising had produced the effect he had commanded. But to return to plain fact. The Academy of Sciences of Copenhagen deputed Professors Forchhammer, Worsaae, and Steenstrup, to examine and report on these curious shell-beds, and the constitution of this commission, consisting of the most eminent geologist, antiquarian, and naturalhistorian of Denmark, ensured a careful investigation. Success, such as the most sanguine could scarcely have anticipated, crowned their labours. It soon became evident that the remarkable deposits they were called on to examine could not be raised beaches. The 
shells which form the largest portion, indeed, in some cases, almost the entire mass of these beds were found to be chiefly those of four species,- the Oyster (Ostrea edulis), the Cockle (Cardium edule), the Mussel (Mytilus edulis), and the Periwinkle (Littorina littorea), -of which the first and last have not a common habitat, and therefore could scarcely be deposited in such enormous quantities, in the same place, by any natural causes. Further, it was observable that the specimens were all adult, while in true raised-beaches immature individuals invariably occur. Then came the consideration that in most cases there was a total absence of shingle or sand, and no appearance whatever of stratification, peculiarities which must have been found had the older hypothesis been correct. When at last it was noticed that most of the smaller bones discovered had had their ends bitten off, and the larger ones had been generally split along the shaft, as if to extract the marrow they contained, the evidence became irresistible, and the connection between them and the flint-implements, found in juxta-position, was clearly seen. In a word, it was plain that these mysterious deposits were the refuse heaps-the very Montes testacei-or, as the Danes now call them-the "Kitchen-Middens" of the ancient inhabitants of the land. This conclusion once arrived at, Archæology claimed and obtained the principal share of the investigation-but, of course, that subject is beside my present purpose. Meanwhile, important results followed from the examination of the Zoological specimens. I have mentioned that the shells were principally of four species. The Common Oyster was the most abundant. It has now disappeared from all the region situated further inland than the Cattegat, and in that strait it is at present only met with here and there in two or three spots, and not in sufficient numbers to supply the Copenhagen market. The inference to be drawn from this fact is, that in those days the water of the Baltic contained more salt than it now does, an inference corroborated, I believe, by geological evidence, which serves to shew that formerly the tides of the German Ocean had freer access thereto through channels which existed prior to the consolidation by upheaval of what is now Jutland. It is also observed, I understand, that the Cockles and Periwinkles, on which the ancient settlers of the realm of Denmark 
feasted, were much better grown than those which, at the present time, inhabit the merely brackish waters of the modern "East Sea." Interesting as is all that pertains to these "nameless pyramids" left by a forgotten race, there is only one other peculiarity upon which I will here dwell. Among the relics recovered from them are a good many birds' bones, belonging to several species, of which some are those of the Capercally, or Cock-of-the-Wood (Tetrao urogallus), a species not only now absent from the Danish beech forests, (which are of vast extent and form so characteristic a feature in the landscape of most parts of that kingdom, ) but not even known to have existed there within the historical or traditionary periods. Nor are these facts suprising, for this fine bird lives chiefly on the tender shoots of the Scotch-fir (Pinus sylvestris), and is only found in regions where that or some nearly allied tree flourishes abundantly. But although the occurrence of the Capercally's bones in these ancient "dust-bins," proves that once the soil of Denmark must have been clothed with pine woods, an examination of the so-called "Forest-Mosses" of that country (also conducted by Professor Steenstrup) shews that prior to the modern growth of beech-groves, themselves of very great antiquity, there was an epoch of oaks, extending over several generations of trees; and before that, again, was the æra of pine-woods, of which the remains are found plentifully in the peat. And thus the enormous remoteness of the period when the "Kjökken-Möddinger" were deposited is testified. I may add that in the autumn of 1859 , I myself had the pleasure of personally inspecting many of the results of the researches I have here so briefly mentioned, which are displayed in the Museam of the University of Copenhagen and that of the Royal Society of Northern Antiquities. Mr. Darwin, in his entertaining and instructive "Naturalist's Voyage" (chap. x.), has acquainted us with the existence of a race of men, inhabiting Tierra del Fuego, who subsist almost entirely on shell-fish, and within the last few weeks, I see that a communication has been made to the Ethnological Society ("Athenæum," 8th iMarch, 1862,) on the shellmounds of the Malay Archipelago, which seem to show a remarkable analogy to the Kitchen-Middens of Denmark; but as yet the only deposits of a corresponding character, which have been observed 
in Europe, are, I believe, some near Mentone, on the gulf of Genoa, the contents of which have not hitherto been fully described.*

By permission of the President of Magdalene, I am enabled to shew you to-night a few Scandinavian antiquities such as I have been alluding to. They form part of a small collection made either in Denmark or Norway by Mr. George Hillman, formerly a member of my own College, at whose death, about twenty years ago, they were presented to the College, and are now preserved in our library. Two flint hatchets, and a beautifully executed spearhead in the same material, exhibit the style of manufacture, and a small bone, flattened and very highly polished on one side, which has, perhaps, been used, as a skait, are among the number. I regret to say I have not had the opportunity of ascertaining to what quadruped the latter has belonged.

Of the ancient Lake Habitations of Switzerland-the "Pile Buildings" to which I before alluded-I can only speak at secondhand. As far as I am able to judge from the published accounts, they seem to furnish results more valuable in an antiquarian than in a zoological point of view. However, they are too interesting to be passed unnoticed here. It appears that from certain climatic causes, in the summer of 1854, the waters of most of the Swiss lakes-whose beauty yearly attracts so many hundreds of our countrymen-shrunk far beyond what had ever been before known. The thrifty occupiers of the land on their borders were not slow to seize this opportunity of adding to their patrimony what the waters had abandoned, and, in the course of the reclaiming operations carried on in consequence, great numbers of piles, stag's horns, and implements, both of stone and bronze, were turned up out of the soil. The attention of the suvans of Switzerland was drawn to these discoveries, and they were shortly able to announce to the world the astonishing faets, that at some period, long anterior to

* In the course of last year, I recollect reading a notice of some beds of perhaps similar formation existing, if I am not mistaken, on the coast of Yorkshire, between Scarborough and Whitby. But I regret to say I omitted to make a note of the circumstance, and I am therefore unable to quote my authority. I should be very glad if this mention of the fact would lead to further investigation of that district, with which I am personally unacquainted.

B 2 
any which history describes, the margins of these lakes were thickly studded with populous villages, apparently built of branches of trees plastered with clay, and supported on piles driven in the water. The inhabitants of these wattled huts-or at least the latest of them-seem to have had a rude knowledge of agriculture, and to have kept domestic cattle, while the earlier settlers probably subsisted entirely on the spøils of the chase. Now, as these people, in common with their northern brethren of the Danish Kitchen-Middens possessed the habit of shooting their rubbish at their cabin doors, we are in a position to form a very fair estimate of the Fauna of pre-historic Helvetia. MM. Keller,* Troyon, $†$ Morlot, $\ddagger$ and others, have in several publications described these "frail memorials" of a bygone age, while M. Rütimeyer§ has especially occupied himself in studying the animal remains removed from them, and thus there have been recognised more than thirty species or races of Mammalia, eighteen of Birds, two of Reptiles, and nine or ten of Fishes. Nor is this great abundance of animal remains at all out of proportion, when the number of settlements whose former existence is thus indicated, the great space over which some of them extended, and the length of time they probably continued, be taken into account. One of them, at Morges, on the Lake of Geneva, is supposed to have been twelve hundred feet long, and one hundred and fifty feet in width, giving an area not much less than the largest Kitchen-Midden, and according to M. Troyon's computation, which is endorsed by Mr. Lubbock as a very moderate one, might have accommodated 1,200 souls. On the same data, the population existing-perhaps it is too much to say co-existing, though the villages are all characteristic of the same period of stone-on the lake of Neuchâtel, may have been 5,000. The sites of nearly seventy settlements belonging to the Bronze age, are stated to have been discovered in the western half of Switzerland alone, and "may be supposed to have contained 42,500

* "Mittheilungen der Antiq. Gesellsch. in Zurich," 1854, 1858, 1860.

† "Habitations lacustres," \&c., Lausanne: 1860.

\$ "General Views on Archæology." Translated by Philip Harry. Annual Report of the Smithsonian Institution for 1860. Washington: 1861.

$\S$ "Die Fauna der Pfahlbauten," \&c. 1861. 
persons, while for the preceding epoch [the Stone age] the population may, in the same number, be estimated at $31,875 . "$

Of the thirty Mammals whose remains have been identified, I will only here dwell upon a few which seem to demand a special notice, from their being either nearly or quite extinct in Switzerland at the present time. The Bear' (Ursus arctos) still maintains itself in the Jura, the Valais, and some of the more remote parts of the country, but at Moosseedorf, near Berne-the city and canton now called from it-its remains testify to its ancient predominance in the land. The Elk (Alces europceus) is now only known to exist in the northern and eastern regions of Europe-Scandinavia, where a judiciously enforced game-law preserves it from extinction-and part of Prussia, where it was all but extirpated in 1848, like many another less nobly crowned head suffering from the license of the revolutionary year. Its remains have been found in many of the Swiss settlements, but in no great numbers, even at that early time.* Of the Ibex (Capra ibex), but a single specimen has been found. This to me does not signify its former rarity, but only, (the Pile-Buildings being situated at some distance from its rocky haunts, ) the probability that it would be seldom brought home by the hunter, who would consume it on the spot where he killed itץ; and to the

* I take this opportunity of observing that there is reason to think it may onccthough probably at a very remote period-have inhabited the British Islands. Professor Owen suggests (Br. Foss. Mamm., p. 483) that a pair of antlers from a marl-pit in Forfarshire, said to be those of the Elk, might possibly prove to be only those of a Reindeer, but I may state that the painting of this specimen, now cxisting in Edinburgh, which that learncd naturalist had not, I believe, then seen, plainly shows it to have been rightly assigned to the Alces europous. See Mr. Wolley's note in "Zoologist," p. 2345.

$\dagger$ I may aad that within the last few days I have been shewn by Mr. Harry Seeley, in the Geological Museum here, a pair of horn-cores, which can only belong to an Ibex, and which were found in a gravel-bed at Fulbourn, in this neighbourhood. I am not awarc of any previous recognition of similar remains in England. The fact is at least a curious one, for one cannot imagine where a range of mountains, suited to its Alpine predilections, could have existed in the vicinity, and it may, perhaps, lend colour to the supposition that the fossils from this formation may have had their origin in places vcry far removed from where they are now found. The cursory examination of this specimen, which $I$ have been kindly permitted to make, offers another point of interest. The vcry small space between the horn-cores approximates the animal much more nearly to the Siberian form (Capra sibirica) than to the European ( $C . i b e x$ ), in which the horns spring from the head at a greater distance from each other, and at once diverge at a greater angle. If I am not mistaken in this observation, and I must say that I have had no other specimens with which to compare it, it furnishes additional confirmation of the Arctic character of the Fauna of the Drift period, which has been already so well pointed out by Professor Owen in his paper on the Musk Ox (Ovibos moschatus). Journ. Geol. Soc., vol. xii., pp. 124-130. 
same cause, also, I should attribute the discovery of a single bone only of the Chamois (Capella rupicapra). A few relics of a very large species of Wild $\mathrm{Ox}$, with long horns, which has been identified (and in all probability rightly so) with the Bos primigenius of geologists and the Urus of Cæsar (Bell. Gall. vi., 28), have also been met with in the Swiss lake-beds. This species has been so very commonly confounded by writers with the Zubr, or European Bison (Bison bonasus)* - the Aurochs as it is commonly, though erroneously, called in France and England-that it is not easy to make out anything with certainty from old writers respecting it. The question is a very interesting one, but it is also one so full of details that I must here be excused from entering upon it. In truth, the two species are entirely-even, as Professor Owen has said, generically-different. Both seem to have once occurred over the greater part of Europe. The Urus, no doubt, no longer exists in a wild state, and is completely extinct, unless it has left descendants among our breed of long-horned cattle, or that half-reclaimed race, which exists by favour of a few landed proprietors in this Island, as at Chillingham, at Hamilton, and at Chartley; but in this case the stock must have degenerated sadly from the gigantic stature of its ancestors, described by Cæsar as "magnitudine paulo infra elephantos," and of which you yourselves may form an idea-supposing that Cæsar has somewhat over-estimated its size-from the portion of the skull and horn-cores on the table, which are from the peat near Ely. In connexion with the present subject, you may notice the very plain marks of a frontal fracture, an injury which, it is observable, must have been inflicted almost simultaneously with the animal's death, since there is no appearance of the broken edges having begun to heal. The European Bison, the remains of which occur at a single settlement on Lake Constance, unlike the Urus certainly flourishes yet in a wild state, but thanks only to the con-

* This has been especially done in a paper, which, however, contains much useful information, by Dr. Weissenborn (Mag. Nat. Hist., new series, ii., pp. 239-256). Far more accurate is the account given by Prof. Nilsson ("Skandinavisk Fauna," Första Delen. Däggdjuren, Lund: 1847, pp. 537-582), of which an Englisl translation has been published. (Ann. and Mag. Nat. Hist., second serics, iv., pp. 256, 349, and 415.) An excellcnt serics of papers on the "Spccies of Bovine Animals," by an anonymous author, has also appeared in the "Indian Field," and been re-printed in England. (Zoologist, 1859 pp. 6360, 6414, 6475, 6506, 6547, and 6700.) 
servative tendencies of the Russian Government. In the forest of Bialowieza, in Lithuania, a small herd is still carefully kept, and perhaps some gentlemen may remember that about fourteen years ago, at the instance of 'Sir Roderick Murchison, the late Emperor Nicholas presented a pair of these fine brutes to the Zoological Society of London, in whose gardens, after thriving for a time, they fell victims to pleuro-pneumonia. A very interesting account of the habits of this species has been given by M. Dimitri de Dolmatoff (Proc. Zool. Soc., 1848, pp. 16-20), who is the head ranger of the forest in which they are now found. Here I will close my notice of the Fauna of ancient Switzerland, for the remains of the Birds, Reptiles, and Fishes from the Pile-Buildings, do not present much general interest.

Now the fact of tribes of men living under the curious conditions just mentioned is not a solitary one. The Swiss investigators have shewn the parallel which in this respect exists between their own former countrymen and the savages of various other lands even at the present time, and it will no doubt be in the recollection of many who hear me that Herodotus (Terpsichore, cap. 16) describes a similar habit as obtaining among the Pæonians, who lived upon Lake Prasias, in Thrace, in dwellings (I quote from Cary's translation) "contrived after this manner: planks fitted on lofty piles are placed in the middle of the lake, with a narrow entrance from the main land by a single bridge. These piles that support the planks all the citizens anciently placed there at the common charge; but afterwards they established a law to the following effect: whenever a man marries, for each wife he sinks three piles, bringing wood from a mountain called Orbelus: but every man has several wives. They live in the following manner; every man has a hut on the planks, in which he dwells, with a trap-door closely fitted in the planks, and leading down to the lake. They tie the young children with a cord round the foot, fearing lest they should fall into the lake beneath" - a precaution very necessary, as may be inferred, from the fact that of the few human skeletons that have been found in the ruins of the Swiss "Pfahl-Bauten" the majority are those of children, and their presence there may be safely ascribed to fatal accidents, arising from casual tumblings over-board. To this 
instance of the "hydrophile" habits of European races, M. Troyon adds some remarks on the Pile Buildings of.New Guinea, as observed by M. Dumont d'Urville, and mentions that indications of the like structures are to be found in the ancient Crannoges of Ireland, and perhaps in England and Denmark.

There are indeed strong grounds for believing that uncivilized races in every part of the world once possessed habits almost identical. The learned and amiable Professor Thomsen, who so ably directs the magnificent Museum of Northern Antiquities at Copenhagen, was, I believe, the first to observe the correspondence between the rudest implements of different tribes, ethnologically extremely remote. Thus the stone-hatchet I lay on the table, which I myself brought from an island in the Caribbean sea, differs in no marked character from some of those "celts" which are discovered in this country, as shewn by one Professor Babington has kindly lent me, found at Burwell in the present year, and the correspondence exists in far too many instances to be merely fortuitous. So also Dr. Wilde, in his "Catalogue of Irish Antiquities," remarks (p. 252): "The more we study man in his primitive simplicity, and collect examples of his arts, as existing among savagge people, the more we are driven to the conclusion that in certain phases of life and states of progress he acts as if by a common instinct or impulse to fulfil the like purposes, provide for the same necessities, and, prompted by similar desires, to follow the same stages of development, merely modified by climate, the natural productions of the country he inhabits-and by race; the latter influence coming into play as he rises from the self-supporting nomad to that condition where men live in community, and depend upon each other, not merely for the luxuries, but the necessities of life."

With these preparatory observations I venture to lay before you a brief account of some relics not dissimilar in character from those which have been found in Switzerland, but on a much smaller scale.*

* 23rd April, 1862. At the time of my reading this paper to the Society, I was fully uncler the impression that I was making public this discovery for the first time, but my kind friend Professor Babington shortly after informed me that on the 1st of March, 1858, he announced the principal facts of the case to the Cambridge Antiquarian Society, from information he had received from my brother, Mr. Edward Newton, of Magdalene, now Assistant Colonial Secretary at Mauritius, and they will be found in the published "Communications" made to that Society (No. VIII., pp. 339-341). 
The principal interest they possess arises perhaps from the fact of their having been discovered here in England, where nothing of the sort, as far as I am aware, had previously been recognised. A few miles from the town of Thetford, near which I commonly live, the country is characterized by a considerable number of natural ponds or meres, varying in size from twenty roods to fifty acres. Many of these are situated in the parishes of East and West Wretham, and one of them, some five or six acres in extent, known as West Mere, in the parish last-named, was in the year 1851, drained of its waters by the proprietor, Mr. Birch, of Wretham Hall, to whom I am under great obligations for his ready kindness in furnishing to my brother and myself the following information. In this mere there was ordinarily about four feet of water, and beneath it, about eight feet of soft black mud, partly held in suspension, and requiring to be removed in scoops. When the mud was being cleared out a great number of bones were discovered, chiefly deposited, as from its semi-liquid nature might have been expected, at the bottom. They were nearly all those of the Red Deer (Cervus elaphus) and the now extinct Bos longifrons, but among them also was the upper part of a Goat's skull, with the horn-cores, and the skull of a Boar or Pig of some sort. Near the centre of the mere, lying below the black mud, was found a ring or circular bank of fine white earth (of which I place a sample before you), sufficiently solid to allow Mr. Birch to ride upon it without yielding to the weight of his pony; indeed it seems to have been about as firm as average sea-sand when damp. Outside this ring, the bottom of the mere was so soft and deep as to be almost impassable until the mud was cleared away. The ring or bank was some twenty or thirty feet across, a foot wide, and about four feet in height. Not far from its inner circumference was a circular hole, about four feet and a half in diameter, some six feet deeper than the bottom of the mere, and, as my informant states, almost like a well to look at. The mud it contained was even softer than that elsewhere. This was marked out by a circle of stout stakes, or small piles, apparently of alder (Alnus glutinosa), and it bore traces of having been wattled. It was not in the centre of the ring, and between the two circles were the remains of a wall, composed of flints packed together with marl or soft chalk. In the 
same place was some earth of a bright blue colour, which, when dried, crumbled to powder, and was not preserved, though you will observe traces of it on some of the bones I shall presently exhibit. In this interspace a still greater number of bones were found, and also the remains of a rude ladder, but in such a state of decay it could only be pulled out piece-meal. Still enough of it was seen by Mr. Birch in situ, for him to have no doubt as to its original form. Its sides were about fifteen inches apart, and its rounds about the same distance from one another. The stakes appeared to have been riven from trees some four inches in diameter. They were very hard, as heavy as stone, and of a dark grey colour. The fragments of the ladder, on the contrary, were very rotten and light, but the remains of both, after being kept some time, exfoliated and crumbled entirely to dust. In and around this ring, as I have said, there lay a vast number of bones, of which no small portion were the upper parts of the skulls of Bos longifrons, with the horn-cores attached, and many antlers of the Red Deer, either entire or in fragments. All the former, excepting one unusually large example, had a fracture in the forehead, as may be partly seen in the specimen now on the table. I believe that hitherto no decisive evidence has been adduced to prove that in England the Long-fronted Ox was contemporary with man, but the appearance of these skulls removes all further doubt on the subject, and corroborates the conjecture put forth several years ago by Professor Owen (Br. Foss. Mamm. p. 514), that this species was probably domesticated by the aborigines of Britain before the Roman invasion. Of the Deers' antlers, some have certainly been shed in the due course of nature, as appears by the fragment I now offer for your inspection. Others, on the contrary, have been separated from the head by sawing, as is conclusively shown by a specimen Mr. Birch kindly allows me to display to you to-night. You will observe that in this case the operator, probably through inadvertence-for the corresponding portion of the fellow antler bears no such tracefirst set to work at this bone above the "burr" or junction with the skull, but that, after a few strokes with his tool, he seems to have thought better of it, and finished the job by cutting off a portion of the skull with it. To what use these bones have been put I do not take on myself to suggest, nor is that in accordance with my 
present object. It may not be uninteresting to compare the excellent handiwork of this early British sawyer, with a much more recent though still ancient bit of a Rein Deer's antler, brought by me from Lapland, where it formed one of a large collection of similar offerings, now I believe scattered, at an old Lapp Altar at Jerisjärwi. In this the marks of some six or seven blows of a hatchet are plainly visible, and testify either to the clumsiness or bad tools of the operator, who probably at last effected his purpose by breaking off the half-severed bone by main force, as the appearance of the surface leads one to suppose. Of the other bones found in West Mere, and I am told there were hundreds of them, most of the larger ones have been fractured at one or either extremity, doubtless in order to extract the marrow they contained. But you will observe by the examples exhibited that they have not been split longitudinally, as is the case with the marrow-bones found in the Danish Kitchen-Middens, and we may perhaps infer from this fact that something like the long horn spoons which we now have for that purpose were in use amongst these ancient gourmêts. Another bone, and, as far as I can make out, the only one found which presents this peculiarity, has been polished on one side, but the reason why is not very obvious unless it has served, as I before suggested in the case of a similar specimen, for a skait. It appears to have belonged to the Long-fronted $\mathrm{Ox}$, and my motive for exhibiting it, as well as dwelling upon these other circumstances, is only to strengthen the truth of Professor Owen's conjecture, to which I have already referred, as to the probability of that species having been domesticated by former races of men in this country, and hence the possibility of its being the progenitor of some of our modern breeds of cattle. I must add that no weapons or implements of metal, which can be referred to a period at all remote, were brought to light in this or any of the adjoining meres, but a great number of flint disks were found, which, according to the description I have received (for unfortunately none of them seem to have been preserved), must have closely resembled those known to the Danish antiquarians as "sling-stones," from the probable use made of them. It is very much to be regretted that no person with a due knowledge of Archæontology was present to have investigated the disC 2 
coveries I have here briefly described at the time they were made. I myself, though in the neighbourhood at the time, did not hear of them until two years afterwards, when all traces had been removed, and the water again let into the mere; yet Mr. Birch, with a praiseworthy zeal, not only preserved many of the more interesting relics, but made some memorandums respecting them, from which my account has been compiled. A few years later, in 1856, the largest of all these meres, having an area of about forty-eight acres, was emptied and cleaned out, and during the operation the spot was visited by Sir Charles Bunbury, who, it is needless to say, is a gentleman of high scientific acquirements, and he has recorded his observations thereon in the "Quarterly Journal of the Geological Society of London" (vol. xii., pp. 355, 356). Valuable as they are, they do not, however, extend to the curious facts $I$ have just recounted, which apparently were not known to him. He has most kindly given me leave to make use of his statements, and I accordingly avail myself of his permission to quote the following extracts from his paper:-

"The water has been drawn off by machinery, for the purpose of making use, as manure, of the black peaty mud which formed the bottom. This black mud, which is in parts above 20 feet deep, is nothing else than a soft, rotten, unconsolidated peat; or perhaps it should be described as vegetable matter in a more complete state of decomposition than ordinary peat, showing no distinct trace of vegetable structure. At the depth of about 15 feet, in this peat, occurs a distinct horizontal layer, from two to six inches thick in various parts, of compressed but undecayed moss, unmixed with any other substance. The stems and leaves of the moss, though closely matted together, are easily separable, and are in so good a state of preservation as to show their distinctive characters very clearly under the microscope. All that I have examined belongs to one species-Hypnum fluitans; a moss by no means uncommon in watery bogs and fenny pools throughout the British Islands, and often growing in dense masses in shallow water. The layer that I speak of is of considerable extent, although apparently not extending over the whole area of the mere, as there are parts in which the whole thickness of the black mud has been penetrated without 
finding it. While wet and fresh, it is of a bright rusty red colour, turning to a yellow brown when dry. What is remarkable, I think, in this case, is the occurrence of a distinct bed of moss, perfect and undecayed, beneath 15 feet of mud, in which no trace of moss is to be seen. **** The black peaty mud (which is of the same quality beneath as above the layer of moss) rests on a bed of light grey sandy marl, which effervesces briskly with acids. This is the lowest stratum that has been reached, owing to the difficulty of keeping out the water. I could find no trace of shells, nor learn that any had been found, either in the peat or the marl. Wood is found in the peat, though not in great quantity: we found some pieces, apparently of birch, and saw the trunk of considerable size, I believe of an oak, which had been lately dug out. **** Numerous posts of oak-wood, shaped and pointed by human art, were found standing erect, entirely buried in the mud."

These remarks, it must be remembered, refer exclusively to the Great Mere at Wretham, and not to the smaller pool, the peculiarities of which were described by Professor Babington, in the paper I have already cited, and by myself here. Yet on the strength of Sir Charles Bunbury's concluding statement, M. Troyon (Hab. Lacustr., p. 91) does not fail to recognize the similarity between the Norfolk antiquities and the Pile Buildings of his own country, much more therefore would he certainly be inclined to declare the facts I have just stated to be indications of true lacustrine habitations in England.

Some weeks since, when examining the large collection of ancient remains in Mr. Birch's possession, all of which were, I believe, found on his estate in Norfolk, I found to my surprise some specimens far more interesting than any $I$ had expected to meet with. These, also, by that gentleman's kindness, I have the pleasure of exhibiting to you. They consist of some limb-bones and a considerable portion of the dorsal and sternal shields of two individuals of the European Fresh-water Tortoise (Emys lutaria)-a species, the existence of which at any time in the British islands has never before been suspected. These were found, as a label upon them in Mr. Birch's handwriting testifies, so long ago as June, 1836 , in a peat bog, by the side of a spring-pit, at East Wretham, 
about seven feet below the surface, and beneath some fifteen hundred laminations of a species of Hypnum, specimens of which were, I understand, submitted by Mr. Birch to Sir William Hooker, who declared the species to be Hypnum filicinum. I immediately communicated these facts to Professor Owen and Professor Bell-as being respectively the highest authorities on the fossil and recent reptiles of this country - and subsequently sent the remains to the first-named gentleman, who kindly determined the species for me, thereby confirming the view I had taken of them, but adding that they were somewhat larger than modern examples from Germany, now in the British Museum. Now, I am told, that no trace of Testudinate remains has been previously observed in England in any formation of a later date than the London clay, certainly not in any post-tertiary deposit. I therefore think I am justified in presenting them to your notice, as being especially worthy of your attention. But this is not my only motive for so doing. I am anxious to point out, in this instance, another of the many coincidences which existed in days of yore between the fauna of Ancient Britain and the faunas of the continental countries nearest to our island. At the present time the geographical range of this little Tortoise is somewhat remarkable. I am not aware of any indication of its existence in Holland, Belgium, or the north of France. In central Germany it is unknown, but it occurs in Bavaria and Austria, as also in Hungary, Poland, and Silesia, whence it extends in a north-western direction through the east of Prussia as far as Rostock in Mecklenburg. In these days it is not recognised as an inhabitant of either Denmark or Sweden, but that it existed in both countries formerly may be seen by the following abstract of the statements of Professors Nilsson and Steenstrup.

The first notice of the discovery of a fossil Tortoise in Sweden seems to be by Professor Dalman, who gives an account (Vetensk. Acad. Handl., 1820, II. p. 286, tabb. vi., vii.) of some remains found in digging the Götha canal, near Norsholm, in Estergöthland. They appear to have been in peat earth, over which a bed of gravel had been super-imposed. About twenty years later Professor Nilsson (Vetensk. Acad. Handl., 1839, pp. 194, 210) noticed a like discovery made in two places-Gräfve in the pastorate of Brågarps, and Fuglie 
in that of Hvällinge-both in Scania, and then pointed out what seemed to him to be some differences between the well-known Emys lutaria and the Swedish examples; which he separated as "var. borealis." In 1842, the same naturalist states (Skandinavisk Herpetologi, p. 11, note) that more than twenty years previously he had received, through a student, a living specimen of the European Water-Tortoise, captured near Falsterbo, the extreme south of Sweden, which at the time he thought must be an imported animal, accidentally escaped, and so neglected to make further enquiries respecting it. He likewise added that he had recently obtained from another source fragments of a fossil Water-Tortoise found in a moss in Elland. This he identifies with the modern Emys hutaria, and appears content to allow his own variety "borealis" to sink into oblivion as if doubtful of its validity even as a local race.

For the occurrence of Tortoise-remains in Danish bogs, I can only refer to a statement made by Professor Steenstrup (Overs. Vid. Selsk. Forhandl., 1848, p. 74) respecting an imperfect example of the "Emys lutaria, var. borealis Nilsson," found in a moss at Overdraaby, in Zealand; while a few years later he announced (Overs. \&c., 1855, p. 1) the discovery of the dorsal and sternal shields of another individual in a moss at Egholm, not far from the last-mentioned locality, and it is also stated (Op. cit., p. 184) that the remains of a third-but smaller and younger example-had since been obtained at the same spot.*

But time presses, and though I would willingly remark on several other species-whose range in Europe was formerly either much more extended than it now is, or which have become altogether extinct within its confines-I can allude to but few of them.

Of the first of these classes there is the Rein Deer (Rangiferimus tarandus) stated by Cæsar to have been an inhabitant in his time of the great Hercynian forest, but which we now only know as a denizen of the arctic or sub-arctic regions of Europe. My chief reason in mentioning it here is one I trust my present audience will excuse, for it is to point out what seems to me a most singular instance of persistent terminology. Cæsar begins his notice of this animal in the words "Est bos, cervi figurâ" (Bell. Gall. vi., 26), and it is remarkable that in Sweden and Norway, where it yet flourishes,

* It is one of the two reptilian species of which traces have been found in a Swiss lake. 
the terms bull, cow, and ox, are at the present day always applied to the Rein Deer, instead of hart or hind, buck or doe. So also in the fur countries of North America, where a form perhaps not to be distinguished from the European species occurs, the same pecularity obtains, since it is known as the Carriboo or Carré-bœuf, a corruption of Cerf-bœuf or "Stag-ox" (Fauna Bor.-Amer. i. p. 238).

Then, again, there is the Wolf (Canis lupus), whose extirpation in Wales is commonly attributed to the measures taken by Edward I., but which certainly was found in the north of England in the reign of Henry VIII., and continued in Scotland until at least 1680, and in Ireland until 1710. But it is, perhaps, of more consequence that I should mention the Wild Boar (Sus scrofa), which was certainly, as its remains now testify, once by no means uncommon in our fen districts, but of which we have no sure knowledge as a member of the British Fauna later than the period of Henry II.--some seven hundred years ago. It is rather remarkable that of the remains of this animal from the peat, the lower jaws seem to be more numerous than any other parts of the skeleton, and these most generally exhibit-as may be seen in the specimen on the table-the effects of severe injuries inflicted near the posterior end of one of the rami. I have observed this in so many instances that I cannot think it the result of accident, and I am disposed to attribute it to human means, just as with the fractured foreheads of the two species of oxen I have already mentioned to you.*

Of the Beaver (Caster fiber), I can only pause to say here that in ancient times it probably inhabited almost the whole of Europe, and its former presence in our fenny districts is testified by numerous remains. In England we have, I believe, no historic evidence concerning it, but it appears to have inhabited Wales till nearly the end of the twelfth century, when it was spoken of as still existing by Giraldus Cambrensis. In France a few survivors may yet linger

* Mr. A. D. Bartlett, the able Superintendent of the Gardens of the Zoological Society of London, has lately thrown a doubt on the supposition hitherto generally received that our tame Pigs are descended from the European Wild Boar. This doubt is based on the undeniable fact that in the latter, "the young are always striped at birth, and in no instance is this marked character found in any of our domestic breeds." (Proc. Z. S. L., 1861, p. 264.) Professors Riitimeyer and Steenstrup are also inclined to the same belief. Dr. Gray, however, has more recently expressed an opinion exactly opposed to Mr. Bartlett's (Proc. Z. S., 28th January, 1862, Ann. and Mag. N. H., Ser. 3, vol. ix., p. 415). 
on the Rhone, but I do not know that it has been of late observed there. In some parts of Germany it still maintains a precarious existence, but the time is nearly at hand when its disappearance must be looked for. Professor Blasius (Säugeth. Deutschl., p. 407) informs us that it was found in 1848 on the Elbe, between Magdeburg and Wittenberg. In the Altmark, on the Havel, the Oder, and the Weichsel, as also in East Prussia, it has been more lately met with, and in 1857, the date of that author's excellent work,* it yet dwelt in Silesia, besides being supposed to be extant in Poland and Lithuania. But in Sweden and Norway its extermination is, I fear, accomplished. In the latter country a law was passed, some eight years ago, prohibiting, under heavy penalty, anyone from putting it to death, but the remedy came too late, and, in answer to all the enquiries I have made, I cannot get any recent information respecting it. In Lapland some of the last beavers were killed by persons spearing fish at night with torches ("Tjustring") - " burning the water," as it is called in Scotland. My late friend and fellow-traveller, Mr. John Wolley, formerly of Trinity College, took great pains during his sojourn in that country to ascertain particulars of its history, and he obtained from an old man the skull of the very last Beaver known to have been killed within the Arctic circle, some twenty-five years previously, and which had been preserved as a curiosity in his cottage. This specimen is now in the Museum of the Royal College of Surgeons.

I have expatiated chiefly on different members of the Mammalia, but I have now to refer briefly to the second great division of Vertebrata, the class Aves, which contains many species just as interesting, from the manner in which they have been affected by human influences. In proof of this I need only cite the names of the Common Crane (Grus cinerea), and the Great Bustard (Otis tarda), birds formerly using the most unfrequented parts of this country for their incunabula, but which cannot now be considered "British" species in the fullest sense of the term. Turner, who wrote towards

* I must take exception, however, to the statement that the Beavers of Europe and North-America cannot with certainty be separated - "doch ist es nicht gelungen, beide von einander sicher zu trennen" (Op. cit. p. 406). On the contrary, I believe that a very cursory examination of the skulls of each, is alone necessary to show that the differences between them are specific. 
the middle of the sixteenth century, speaks of the former as nesting with us, strengthening his assertion with the words "earum pipiones [!] ipse sæpissime vidi" (Av. Hist. : 1543), but the practice does not seem to have been continued long, in spite of projecting Acts of Parliament, for to Sir Thomas Browne and Ray the Crane was known only as a winter visitant. There are so many persons still living who have themselves seen our native race of Bustards, that I will not here enlarge upon the theme, though it would be agreeable for me to do so, since the greatest part of my life has been spent in the district where they last maintained themselves. I will only add that I believe the year 1838 saw the death of the last truly British Bustard, and that this event, mournful to all who take any pleasure in recollections of the past, took place at Lexham, near Swaffham, in Norfolk. It is perfectly true that, since then, several other examples have been seen or killed in this country-on an average about two in every three years-yet I doubt not they have all been of foreign birth, and most of them have met with that kind of reception which tends so much to disgrace many of the votaries of matural history in England.

I am inclined to think that much light may be thrown on the ancient state of this country by an examination of the birds' bones which are to be found imbedded in our Fens,-for I have already mentioned the unquestionable inferences to be drawn from the discovery of traces of the Capercally in the Danish bogs. Our Geological Museum contains already no small number of ornithic remains from the peat, and I trust it will not be long before they are fully identified. Some bones which I now exhibit from Hilgay fen, in Norfolk, I have made out to be those of the Grey Goose (Anser cinereus), but we have abundant evidence elsewhere that that species, now so rare, and confined in the breeding season to a few Scottish lochs, was formerly plentiful in the east of England. I have also here some specimens, kindly entrusted to me for identification by Dr. Carte, of Dublin, which were found at Dungarvan, in Ireland, and these I suppose to have belonged to the Wild Swan or Hooper (Cygnus ferus), a species which Professor Owen believes he has recognized in remains from the brick-earth at Grays, in Essex, (Proc. Geol. Soc., 1856, p. 211,) a formation in which the bones 
of Elephas primigenius and Rhinoceros tichorhinus are also found in some numbers.

There is but one other demand I will make on your patience: this is in reference to a species undoubtedly possessing much interest, but also one with respect to which I fear my own feelings may perhaps appear too enthusiastic. It is the Gare-fowl or Great Auk (Alca impennis), the only bird of the northern hemisphere to which, for some reasons, - to us inscrutable-the power of flight has been denied. I have recently given an abstract, elsewhere published,* of some researches into its history made in Iceland, in which researches I had the pleasure of assisting a deeply lamented fellow labourer. To that account I hope to be allowed to refer any further enquirers on the subject. I will only say now that Mr. Wolley and I found abundant evidence of the truth of the statements made by former travellers in that country. I have here a few specimens of its bones, which we collected from various "Kitchen-Middens," (of comparative recent date it is true,) and heaps of drifted sand near Cape Reykjanes, the south-west point of Iceland. But the species, which is supposed by many ornithologists to be now extinct, was formerly very plentiful on both sides of the Atlantic, and even on some islands suited to its necessarily peculiar habits around our coast. The statement of its breeding on St. Kilda, which has been often quoted, is very circumstantial, and in Orkney there are still persons living who remember it as a native bird, a fact by no means extraordinary, when it is known that the last example observed there was killed in the year 1812, and its skin sent to Mr. Bullock, at the sale of whose collection it was bought by Dr. Leach for the British Museum, where it may now be seen in very fair preservation. A few of its bones have been discovered in the Danish "KitchenMiddens," and this circumstance has led Professor Steenstrup to publish an excellent little monograph on the species. $t$ Herein he has most carefully collected the notices concerning it which exist in the narratives of old voyages to Newfoundland and the Gulf of St. Lawrence. And notwithstanding that it may be perhaps somewhat departing from the scope of a paper professedly on European zoology,

* "Ibis" 1861, pp. 374-399.

† Vidensk. Meddelelser, 1855, pp. 33-116.

D 2 
I hope it will be permitted me to mention a few of these here. For though most of them are drawn from sources originally published in England, they have never been collated by English naturalists, and they represent a state of things similar in all probability to that which once existed in many localities along the western shores of Europe.

In "The voyage of M. Hore and diuers other gentlemen, to Newfoundland, and Cape Briton, in the yeere 1536," \&c. (Hakluyt, iii., p. 168,) it is stated:-

"From the time of their setting out from Grauesend, they were very long at sea, to witte, aboue two moneths, and neuer touched any land vntill they came to part of the West Indies about Cape Briton, shaping their course thence Northeastwardes, vntill they came to the Island of Penguin, which is very full of rockes and stones, whereon they went and found it full of great foules white and gray, as big as geese, and they saw infinite numbers of their egges. They draue a great number of the foules into their boates vpon their sayles, and tooke up many of their egges, the foules they flead and their skinnes were very like hony combes full of holes being flead off: they dressed and eate them and found them to be very good and nourishing meat."

In "A letter written to M. Richard Hakluyt of the middle Temple, containing a report of the true state and commodities of Newfoundland, by M. Anthonie Parkhurst Gentleman," dated "From Bristow, the 13th of Nouember, 1578," (Hakluyt, iii., pp. 172,173, ) is this passage :-

"There are Sea Guls, Murres, Duckes, wild Geese, and many other kind of birdes store, too long to write, especially at one Island named Penguin, where wee may driue them on a planke into our ship as many as shall lade her. These birdes are also called Penguins, and cannot flie, there is more meate in one of these then in a goose: the Frenchmen that fish neere the grand baie, doe bring small store of flesh with them, but victuall themselues alwayes with these birdes."

Again in "A report of the voyage and successe thereof, attempted in the yeere of our Lord 1583 by Sir Humfrey Gilbert 
knight, \&c., written by M. Edward Haies gentleman, \&c.," (Hakluyt, iii., p. 191) :-

"We had sight of an Iland named Penguin, of a foule there breeding in abundance, almost incredible, which cannot flie, their wings not being able to carry their body, being very large (not much lesse then a goose) and exceeding fat: which the French men vse to take without difficulty vpon that Mland, and to barrell them $\mathrm{vp}$ with salt. But for lingering of time we had made vs there the like prouision."

The passage just quoted is no libel on the French sailors of those days. It is entirely confirmed by the narrative of Jacques Carthier's third voyage. I have not been able to obtain a sight of tho original work, and must content myself with the extract as given by Professor Steenstrup. After speaking of the incredible abundance of birds at the so-called "Ile des Oyseaux," near Cape Bona-vista, the writer goes on to observe:-

"Neantmoins il-y-a cent fois plus à l'entour d'icelle, et en l'air que dedans, desquels les vns sont grands, comme Pies noirs \& blanes, ayans le bec de Corbeau: ilz sont tousiours en mer, et ne peuvent voler haut, d'autant que leurs ailes sont petites, point plus grandes que la moitié de la main, avec lesquelles toutefois ilz volent de telle vitesse à fleur d'eau, que les autres oyseaux en l'air. Ilz sont excessivement gras, et estoient appellez par c'eux du païs Apponath, desquelz noz deux barques se chargerent en moins de demi heure, comme l'on auroit peu faire de cailloux, de sorte qu'en châque navire nous en fimes saler quatre ou cinq tonneaux, sans ceux que nous mangeames frais."*

But I think I need not quote more of these notices. It will be clear to all who reflect that no species could long survive such wholesale destruction as they narrate. I must observe, however, that the accounts are corroborated by relics which yet exist. On a little rock, called Funk Island, to the north-east of Newfoundland, large heaps of Great Auks' bones have been found, and also rude enclosures of big stones-" "pounds" as the fishermen call theminto which tradition says the birds were driven before being slaughtered. A Norwegian naturalist, by name Peter Stuvitz, who was

* Lescarbot, "Histoire de la Nouvelle France," Paris: 1624, p. 241 (fide Steenstrup). 
sent by his government, about twenty years ago, to examine into the Newfoundland fisheries, seems to have been the first to describe these remains. In the report which he made, as appears from Professor Steenstrup's elaborate paper, he alluded to the former abundance in those seas of "Penguins" - the name by which the Great Auk has been long known in the American waters. His statement was received with suspicion by those to whom his report was referred, on the ground that no true Penguins occur in the northern hemisphere. Stuvitz feeling his credit at stake, went specially to Funk Island, and procured thence a number of these bones, which, in proof of the accuracy of his assertion, he transmitted to Christiania, where they were of course recognised as belonging to the Alca impennis. I have myself seen some of these specimens, since transferred to the Museum of the University of Copenhagen, and I hope, through the kindness of a gentleman in Newfoundland, shortly to obtain others. At what period the bird ceased to frequent this and the neighbouring localities I do not know. Some ten years ago I talked with an old man, about seventy years of age, who in his youth had been employed in the Newfoundland fishery, and though the stories of the massacres of old times were quite familiar to him, he told me he had never seen but two or three of the birds himself. We may, I think, therefore, safely conclude that the "Penguins" had become scarce in those seas by the beginning of the present century, while in Iceland we know the "Gare-Fowls" existed as recently as 1844, when the last two, proved with any certainty to have lived, were killed. As far as I have been able to make out, the various museums of the world possess in all about forty-five stuffed specimens of the Great Auk, of which nearly onehalf are comprised in the United Kingdom, and I am glad to say the example belonging to this Society is one of the finest of the whole.*

I thus conclude these remarks-which I well know are far too discursive. The interest I take in the subject to which they refer is such that I would have willingly protracted them. I fear they

* There seem to exist about forty-eight specimens of the Great Auk's egg, of which no less than thirty-four are in the British Islands! In December last, I had the pleasure of finding ten in the Museum of the Royal College of Surgeons, which had not been previously recognized. 
may seem to you already sufficiently tedious, and very barren of results. My object has been chiefly to point out how much still remains to be done, before our knowledge of Archæontology can be said to be placed on at all a satisfactory basis, and I trust that I may at least be the means of awakening both the Archæologists and Zoologists of this University to a conviction--should there be any who have not already entertained it-of the light they can respectively throw on each other's labours, and the deep importance of such mutual assistance. If I have failed to do this, I must take refuge in the general reflexion, applied to this special subject by one of the older Swiss Archæologists-" "The circulation of ideas is for the mind what the circulation of money is for commerce-a true source of wealth."**

* C. V. de Bonstetten, "L'homme du midi et l'homme du nord," Geneva: 1826, p. 175 (fide Morlot). 
Matchett and Stevenson, Printers, Market-place, Norwich. 
